\title{
Volatile compounds from organic and conventional passion fruit (Passiflora edulis F. Flavicarpa) pulp
}

\author{
Compostos voláteis da polpa de maracujá (Passiflora edulis F. Flavicarpa) orgânica e convencional
}

\author{
Mariana Serrão MACORIS ${ }^{1}$, Natália Soares JANZANTTII ${ }^{1}$, Deborah dos Santos GARRUTI², Magali MONTEIRO ${ }^{1 \star}$
}

\begin{abstract}
The volatile compositions from organic and conventional passion fruit pulps produced in Brazil were investigated. The pulps were also physicochemically characterized. The volatile compounds from the headspace of the passion fruit pulp were stripped to a Porapak Q trap for 2 hours; they were eluted with $300 \mu \mathrm{L}$ of dichloromethane, separated by gas chromatography/flame ionisation detection and identified through gas chromatography/mass spectrometry. Both pulps conformed to the requirements of the Brazilian legislation, indicating they were suitable to be industrialized and consumed. A total of 77 compounds were detected in the headspace of the passion fruit pulps - 60 of which were identified, comprising $91 \%$ of the total chromatogram area. The major compounds were the following: ethyl butanoate, $52 \%$ and $57 \%$ of the total relative area of the chromatogram for the organic and conventional passion fruit pulps, respectively; ethyl hexanoate, $22 \%$ and $9 \%$, respectively; and hexyl butanoate, $2 \%$ and $5 \%$, respectively. The aroma of the organic passion fruit pulp is mainly related to the following volatile compounds: ethyl hexanoate, methyl hexanoate, $\beta$-myrcene and $\mathrm{D}$-limonene. The conventional passion fruit pulp presented methyl butanoate, butyl acetate, hexanal, 1-butanol, butyl butanoate, trans-3-hexenyl acetate, cis-3-hexen-1-ol, butyl hexanoate, hexyl butanoate, 3-hexenyl butanoate and 3-hexenyl hexanoate as the main volatile compounds for aroma.
\end{abstract}

Keywords: organic passion fruit; aroma; flavor chemistry; fruit pulp; gas chromatography/mass spectrometry.

\section{Resumo}

A composição de voláteis das polpas de maracujá orgânico e convencional produzido no Brasil foi estudada. As polpas também foram caracterizadas físico-quimicamente. Os compostos voláteis do headspace da polpa de maracujá foram capturados em Porapak Q por 2 horas, aluídos do polímero com $300 \mu \mathrm{L}$ de diclorometano, separados por cromatografia gasosa/ionização de chama e identificados por cromatografia gasosa/espectrometria de massas. Ambas as polpas estavam de acordo com as exigências da legislação brasileira, indicando que estavam adequadas para a industrialização e consumo. Um total de 77 compostos foi detectado no headspace das polpas de maracujá, dos quais, 60 foram identificados, compreendendo $91 \%$ da área total do cromatograma. Os compostos majoritários foram butanoato de etila, com $52 \%$ e $57 \%$ da área relativa total do cromatograma, nas polpas de maracujá orgânica e convencional, respectivamente; hexanoato de etila, com $22 \%$ e $9 \%$, respectivamente; e butanoato de hexila, com $2 \%$ e $5 \%$, respectivamente. O aroma da polpa de maracujá orgânico está relacionado principalmente aos compostos voláteis hexanoato de etila, hexanoato de metila, $\beta$-mirceno e $\mathrm{D}$-limoneno. Na polpa de maracujá convencional, os compostos voláteis butanoato de metila, acetato de butila, hexanal, 1-butanol, butanoato de butila, acetato de trans-3-hexenila, cis-3-hexen1-ol, hexanoato de butila, butanoato de hexila, butanoato de 3-hexenila e hexanoato de 3-hexenila foram relacionados ao aroma.

Palavras-chave: maracujá orgânico; aroma; química do sabor; polpa de fruta; cromatografia gasosa/espectrometria de massas.

\section{Introduction}

Tropical fruits are produced in Brazil on a large scale and represent an important economic activity. Fruit production was approximately 41.2 million $t$ in 2005, being responsible for $13 \%$ of the Brazilian agricultural production, occupying 2.3 million ha and providing 6 million jobs (ALMEIDA, 2008).

Yellow passion fruit is widely produced and consumed in Brazil. Both the fresh fruit and the juice are highly appreciated because of its sensory characteristics. Passion fruit has been grown under both conventional and organic systems. The production of organic food has already reached 30.4 million ha of certified cultivated area in the world, and around 880 thousand ha in Brazil (WILLER; YUSSEFI-MENZLER;
SORENSEN, 2008). The increasing consumption of organic products is related to the consumers' concern with a healthier life style and the need for environmental preservation, which has led consumers to search for good quality food produced without the use of chemical products (SANTOS; MONTEIRO, 2004).

The volatile compounds responsible for the aroma and flavor of foods are present in minute amounts, and those contributing to the flavor of fruits may vary according to the stage of maturity, the cultivar and the edaphoclimatic conditions, amongst others. Organic and conventional cultivation may also affect fruit quality (WILLER; YUSSEFI-MENZLER; SORENSEN, 2008). Abiotic and biotic factors - especially injury

\section{Received 24/7/2009}

Accepted 18/1/2010 (004277)

${ }^{1}$ Department of Food and Nutrition, School of Pharmaceutical Science, São Paulo State University - UNESP, CP 502, CEP 14801-902, Araraquara, SP, Brazil,

E-mail: monteiro@fcfar.unesp.br

${ }^{2}$ Embrapa Tropical Agroindustry, CP 3761, CEP 60511-110, Fortaleza, CE, Brazil

${ }^{*}$ Corresponding author 
through pathogenic insects that affect plants - are responsible for changing the plant physiology and also for inducing secondary metabolite synthesis, leading to important changes in the physicochemical characteristics and in the composition of the volatile compounds, such as terpenes and esters, which are important to the characteristic aroma of passion fruit (HEIL; BOSTOCK, 2002).

The techniques used to study the volatile composition of foods include the isolation, separation and identification of compounds, as well as the sensory analyzes (THOMAZINI; FRANCO, 2000). Porous polymers have been widely used for the isolation of aroma compounds of many fruits, such as: mango, papaya, guava, umbu-caja, camu-camu, araça-boi, сириас̧u, cashew apple, apple and passion fruit (SHIBAMOTO; TANG, 1990; FRANCO; SHIBAMOTO, 2000; JANZANTTI; FRANCO; LANÇAS, 2000; FRANCO; RODRIGUEZ-AMAYA; LANÇAS, 2004; GARRUTI et al., 2003; NARAIN et al., 2004; JALES et al., 2005).

Several volatile compounds have been identified in passion fruit (YOUNG; PATERSON, 1990; ENGEL; TRESSL, 1991; WINTERHALTER, 1991; WERKHOFF et al., 1998; PINO, 1997; JORDÁN; GOODNER; SHAW, 2002; JALES et al., 2005). Esters, terpenes and sulfur compounds are considered to be the most important components of the characteristic passion fruit flavor, with the major group being the class of esters (ENGEL; TRESSL, 1991; WERKHOFF et al., 1998; JORDÁN; GOODNER; SHAW, 2002; NARAIN et al., 2004). Although organic passion fruit has been used in Brazil mainly as juice and pulp, reports on their volatile compositions are not available.

The aim of this work was to investigate the volatile composition of yellow passion fruit, comparing the organic and conventional pulps.

\section{Materials and methods}

\subsection{Materials}

Organic and conventional yellow passion fruits, Afruvec material, were obtained from producers in the Southwest region of the State of Sao Paulo, Brazil, during the 2006 harvest. The organic fruits, certified at the Biodynamic Institute (IBD), Sao Paulo, Brazil, were cultivated in Paulistania, SP (22 $34^{\prime} 42^{\prime \prime}$ $\mathrm{S}$ and $49^{\circ} 24^{\prime} 10^{\prime \prime} \mathrm{W}, 645 \mathrm{~m}$ altitude). The conventional fruits were cultivated in Bauru, SP (22 $19^{\prime} 18^{\prime \prime} \mathrm{S}$ and $49^{\circ} 04^{\prime} 13^{\prime \prime} \mathrm{W}$, $526 \mathrm{~m}$ altitude). $40 \mathrm{~kg}$ of organic and conventional passion fruit at the same stage of development were harvested and immediately taken to the laboratory. The fruits were screened, inspected and washed, and then the pulp was separated from the seeds and peel, which were discarded, leaving the clean pulp. The pulp was packed directly into hermetically sealed $250 \mathrm{~mL}$ glass flasks and stored in a freezer at $-18^{\circ} \mathrm{C}$ until analysis (DE MARCHI et al., 2000; AMARO; MONTEIRO, 2001).

The chemical standards were purchased from Fluka and Sigma-Aldrich (Steinheim, Germany).

\subsection{Physicochemical analysis}

The titratable acidity, $\mathrm{pH}$, soluble solids, reducing and total sugars and ascorbic acid contents of the organic and conventional yellow passion fruit pulps were determined according to AOAC methodology (ASSOCIATION..., 1998). Three replicate analyses were carried out for each sample.

\subsection{Isolation of the volatile composition}

The isolation of the volatile compounds followed the method described by Franco and Rodriguez-Amaya (1983). Three hundred grams of passion fruit pulp were placed in a $1,000 \mathrm{~mL}$ flask with $30 \% \mathrm{NaCl}(\mathrm{w} / \mathrm{w})$, which was used in order to avoid the enzymatic degradation of the volatile compounds. The volatile compounds of the headspace of the passion fruit pulp were sucked by vacuum at room temperature, trapped in a porous polymer trap (100 mg of an 80-100 mesh Porapak Q, Waters Associates, Milford, USA) and then eluted with $300 \mu \mathrm{L}$ of solvent. The polymer was previously conditioned in an ultra pure $\mathrm{N}_{2}$ flow ( $40 \mathrm{~mL} / \mathrm{minute}$ ) at $170{ }^{\circ} \mathrm{C}$ for 8 hours. Three replicates of the organic and conventional yellow passion fruit pulps were analyzed.

In order to obtain the most representative isolate of passion fruit aroma, previous experiments were conducted to choose the best trapping time (1, 2 or 3 hours) and solvent, dichloromethane (Tedia, Fairfield, USA) or hexane (Mallinckrodt, Phillisburg, USA), which best eluted the most characteristic volatile compounds of the passion fruit pulp. A trained and selected panel comprising four judges analyzed the aroma of the isolates in a $9 \mathrm{~cm}$ non-structured scale, anchored by the terms "low characteristic odor" and "very characteristic odor" at the left and right ends, respectively (BASTOS; DA SILVA; FRANCO, 1998; MACORIS; JANZANTTI; MONTEIRO, 2007). Both parameters were analyzed in four replicates.

\subsection{Gas Chromatography/Flame Ionization Detection (GC/FID)}

Prior to chromatographic analysis, it was investigated which column, DB-Wax or DB-1 capillary columns, both from J\&W Scientific (Folsom, USA), showed the best resolution. Then, the GC/FID analyses were performed using a Shimadzu 2010 GC (Kyoto, Japan). The DB-Wax column (30 m length, $0.25 \mathrm{~mm}$ i.d., $0.25 \mu \mathrm{m}$ film thickness) was maintained at $40^{\circ} \mathrm{C}$ for 10 minutes and then programmed to rise to $200^{\circ} \mathrm{C}$ at $5^{\circ} \mathrm{C} /$ minute, where it was held for 10 minutes. The splitless mode injector was maintained at $200{ }^{\circ} \mathrm{C}$ and the FID at $250{ }^{\circ} \mathrm{C}$. Hydrogen was the carrier gas at a flow rate of $1.3 \mathrm{~mL} /$ minute. Three replicate analyses were carried out for each pulp. Semi-quantitative analysis of the compounds was performed by normalization.

\subsection{Gas Chromatography/Mass Spectrometry (GC/MS)}

The identification of the volatile compounds was carried out through GC/MS analysis. A Shimadzu 2010 GC equipped with a Shimadzu 2010 Mass Detector (Kyoto, Japan) was used to obtain the mass spectra data. The column and temperature programs were the same as those used in the CG-FID. Helium was the carrier gas at a flow rate of $1.3 \mathrm{~mL} / \mathrm{minute}$. The injector and detector temperatures were $250^{\circ} \mathrm{C}$ and $280^{\circ} \mathrm{C}$, respectively. Mass spectra data were obtained by electron impact at $70 \mathrm{eV}$, in the scan mode, $\mathrm{m} / \mathrm{z}$ range from 35 to 350 . 
The volatile compounds were identified using both the mass spectra (NIST 1.7) and the literature data (ACREE; ARN, 2008). Retention indices were determined using homologous series of normal n-alkanes, $\mathrm{C}_{10}-\mathrm{C}_{26}$. The identities were confirmed by comparing the relative retention indices of the compounds to those of authentic standards or from literature sources (WHERKHOFF et al., 1998; JORDÁN; GOODNER; SHAW, 2002; JALES et al., 2005).

\subsection{Statistical analysis}

The one-way ANOVA and Tukey's tests were used to compare the average values obtained in the volatile composition and physicochemical analyses (Statistical Analysis System, 1996). Peaks with relative area $\leq 0.04 \%$, near the peak threshold limit for integration, were not submitted to ANOVA.

\section{Results and discussion}

\subsection{Physicochemical analysis}

The Brazilian legislation establishes values of $2.5 \mathrm{~g}$ of citric acid.100 mL $\mathrm{mL}^{-1}$; glucose content lower than 18.0 g. $100 \mathrm{~mL}^{-1}$, $11^{\circ} \mathrm{Brix}$; and $\mathrm{pH}$ values between 2.7 and 3.8; as standards for identity and quality of passion fruit pulp (BRASIL, 2000). All the physicochemical parameters (Table 1) conformed to the requirements of the Brazilian legislation, indicating that the pulps were suitable to be industrialized and consumed. Significant differences $(p \leq 0.05)$ were found between the organic and conventional passion fruit pulps for all the physicochemical parameters, except for the ascorbic acid content. Conventional passion fruit pulp showed higher values $(\mathrm{p} \leq 0.05)$ for acidity, $\mathrm{pH}$, soluble solids and reducing and total sugars than organic passion fruit pulp, which was only higher $(\mathrm{p} \leq 0.05)$ for the ratio. The organic and conventional passion fruit pulps showed almost the same value range for the ascorbic acid content (Table 1).

Amaro and Monteiro (2001) evaluated the physicochemical parameters of organic and conventional passion fruit, IAC-75 material. Values similar to ours were obtained for titratable acidity, soluble solids content and ratio, although slightly higher $\mathrm{pH}$ values were found. Also, ascorbic acid content of passion fruit of about $15 \mathrm{mg} .100 \mathrm{~mL}^{-1}$ pulp, described by Monteiro, Amaro and Bonilha (2005), was also reported by Amaro and Monteiro (2001). In the present study, the passion fruit pulp showed lower ascorbic acid contents.

\subsection{Volatile composition}

The profile of the volatile compounds obtained from the passion fruit pulp using dichloromethane and hexane elution, after separation using DB-Wax and DB-1 columns, were similar, but a better separation of the volatile compounds was obtained using the DB-Wax column, which was, therefore, chosen for the subsequent experiments. The DB-1 column showed some impurities that could influence the analysis. It was observed that dichloromethane eluted a larger number of volatile compounds from the polymer trap when compared to hexane elution. The results indicated dichloromethane as the most efficient solvent and DB-Wax as the highest resolution column, under the studied conditions. Furthermore, dichloromethane isolate showed a greater intensity for characteristic odor (7.37) $(\mathrm{p} \leq 0.05)$. Isolation after 1,2 and 3 hours of trapping presented differences, but with high means (6.91 to 7.75), for intensity of the passion fruit characteristic odor. The highest intensity of passion fruit characteristic odor (7.75) was achieved using 2 hours of trapping, although no significant difference ( $p>0.05)$ was observed between 2 and 3 hours of trapping. Thus, the conditions fixed for the isolation and separation were: 2 hours of trapping; elution with dichloromethane; and DB-Wax column. It should be pointed out that a representative isolate was obtained using these conditions.

Seventy-seven compounds were detected in the headspace of the organic (Figure 1a) and conventional (Figure 1b) passion fruit pulps using GC/FID, 60 of which were identified through GC/MS and retention indices data, comprising $91 \%$ of the chromatogram area. The majority of the volatile compounds was composed of esters (28 compounds), 13 alcohols, 7 terpenes, 6 ketones, 4 hydrocarbons, 1 aldehyde and 1 acid.

Most compounds were the same for both passion fruit pulps. Ethyl butanoate, $52 \%$ and $57 \%$ of the relative area of the chromatogram, in the organic and conventional passion fruit pulps, respectively; ethyl hexanoate, $22 \%$ and $9 \%$; respectively; hexyl butanoate, $2 \%$ and $5 \%$, respectively; were the main compounds (Table 2).

The organic passion fruit pulp showed relatively higher quantities $(\mathrm{p} \leq 0.05)$ of 3 -methylbutyl acetate and ethyl hexanoate, but relatively lower quantities $(\mathrm{p} \leq 0.05)$ of methyl butanoate, butyl acetate, butyl butanoate, hexyl acetate, trans-3-hexenyl acetate, butyl hexanoate, hexyl butanoate, 3-hexenyl butanoate, 3-hexenyl hexanoate and cis-3-hexen-1-ol than the conventional passion fruit pulp.

Table 1. Physicochemical parameters for organic and conventional passion fruit pulps.

\begin{tabular}{lrr}
\hline \multicolumn{1}{c}{ Parameters } & Organic & Conventional \\
\hline Titratable Acidity (g citric acid. $\left.100 \mathrm{~mL}^{-1}\right)$ & $4.26^{\mathrm{b}} \pm 0.04(0.89)$ & $5.11^{\mathrm{a}} \pm 0.01(0.11)$ \\
pH & $3.16^{\mathrm{b}} \pm 0.05(1.45)$ & $3.29^{\mathrm{a}} \pm 0.03(0.93)$ \\
Soluble solids ( ${ }^{\circ}$ Brix) & $13.27^{\mathrm{b}} \pm 0.16(0.87)$ & $14.80^{\mathrm{a}} \pm 0.00(0.00)$ \\
Ratio & $3.11^{\mathrm{a}} \pm 0.03(0.85)$ & $2.90 \mathrm{~b} \pm 0.00(0.00)$ \\
Reducing sugars (g glucose. $\left.100 \mathrm{~mL}^{-1}\right)$ & $3.06^{\mathrm{b}} \pm 0.17(5.40)$ & $4.31^{\mathrm{a}} \pm 0.13(3.03)$ \\
Total sugars (g glucose. $\left.100 \mathrm{~mL}^{-1}\right)$ & $5.51^{\mathrm{b}} \pm 0.07(1.34)$ & $5.97^{\mathrm{a}} \pm 0.09(1.55)$ \\
Ascorbic acid (mg.100 $\left.\mathrm{mL}^{-1}\right)$ & $10.60^{\mathrm{a}} \pm 0.21(1.96)$ & $10.87^{\mathrm{a}} \pm 0.10(0.92)$ \\
\hline
\end{tabular}

Mean \pm standard deviation, relative standard deviation (\%) in brackets, $\mathrm{n}=3$. Means with the same letter in the same line did not differ significantly in the Tukey's test ( $\mathrm{p} \leq 0.05$ ). 
Marcoris et al.
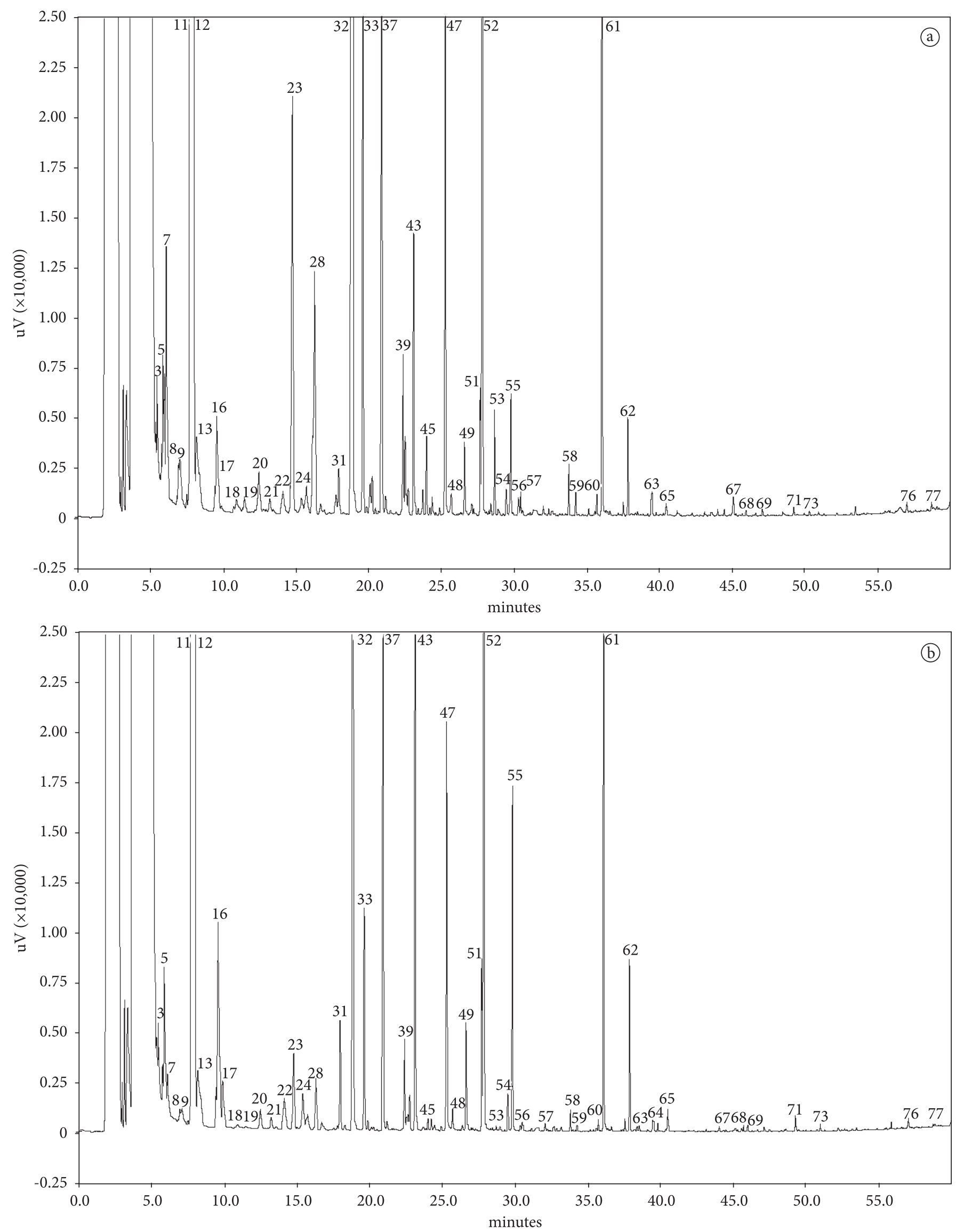

Figure 1. GC-FID chromatograms of organic (a) and conventional (b) passion fruit pulp. 
Table 2. Relative areas ${ }^{1}(\%)$ of the main volatile compounds in organic and conventional passion fruit pulps.

\begin{tabular}{|c|c|c|c|}
\hline Compound & RI DB-Wax & Organic & Conventional \\
\hline propyl acetate & $<1000$ & $0.23^{\mathrm{a}} \pm 0.06$ & $0.24^{\mathrm{a}} \pm 0.02$ \\
\hline ethyl butanoate & 1036 & $52.50^{\mathrm{a}} \pm 4,31$ & $57.34^{\mathrm{a}} \pm 2.77$ \\
\hline butyl acetate & 1072 & $0.45^{\mathrm{b}} \pm 0.02$ & $1.91^{\mathrm{a}} \pm 0.06$ \\
\hline hexanal & 1078 & nd-tr & $0.40 \pm 0,05$ \\
\hline$\beta$-myrcene & 1166 & $1.32^{\mathrm{a}} \pm 0.40$ & $0.58^{\mathrm{a}} \pm 0.01$ \\
\hline methyl hexanoate & 1188 & $0.21 \pm 0,04$ & nd \\
\hline D-limonene & 1190 & $0.88^{\mathrm{a}} \pm 0.29$ & $0.43^{\mathrm{a}} \pm 0.06$ \\
\hline butyl butanoate & 1221 & $0.14^{\mathrm{b}} \pm 0.01$ & $0.56^{\mathrm{a}} \pm 0.05$ \\
\hline ethyl hexanoate & 1239 & $22.37^{\mathrm{a}} \pm 1.48$ & $8.90^{\mathrm{b}} \pm 0.09$ \\
\hline 1-hexanol & 1364 & $1.60^{\mathrm{a}} \pm 0.18$ & $1.78^{\mathrm{a}} \pm 0.32$ \\
\hline cis-3-hexen-1-ol & 1391 & $0.20^{\mathrm{b}} \pm 0.03$ & $0.49^{\mathrm{a}} \pm 0.07$ \\
\hline butyl hexanoate & 1414 & $0.20^{\mathrm{b}} \pm 0.05$ & $0.58^{\mathrm{a}} \pm 0.09$ \\
\hline hexyl butanoate & 1418 & $2.24^{\mathrm{b}} \pm 0.60$ & $4.86^{\mathrm{a}} \pm 0.78$ \\
\hline 3-hexenyl butanoate & 1463 & $0.22^{\mathrm{b}} \pm 0.04$ & $1.10^{\mathrm{a}} \pm 0.19$ \\
\hline hexyl hexanoate & 1613 & $1.55^{\mathrm{a}} \pm 0.66$ & $2.13^{\mathrm{a}} \pm 0.38$ \\
\hline 3-hexenyl hexanoate & 1660 & $0.14^{\mathrm{b}} \pm 0.05$ & $0.53^{\mathrm{a}} \pm 0.10$ \\
\hline
\end{tabular}

nd, not detected; tr, trace $\leq 0.04 \%$ of the total relative area; RI, retention indices. ${ }^{1}$ Area $=$ mean of 3 replicates. Means with the same letter in the same line did not differ significantly in the Tukey's test $(\mathrm{p} \leq 0.05)$.

Some differences in the minor peaks, not included in the ANOVA, were also observed. $\beta$-myrcene and D-limonene were detected in higher quantities in the organic passion fruit pulp, while hexanal, 1-butanol and hexyl hexanoate were higher in the conventional passion fruit pulp. Methyl hexanoate was only detected in the organic passion fruit pulp (Table 2).

Thirteen esters (propyl acetate, 2-methylpropyl acetate, ethyl isovalerate, ethyl carbonate, ethyl valerate, pentyl acetate, prenyl acetate, (cis and trans)-ethyl 3-hexenoate, cis-3-hexenyl acetate, ethyl octanoate, ethyl 4-octenoate, methyl palmitate), eleven alcohols (2-butanol, 2-methyl-3-buten-2-ol, isobutyl alcohol, 3-methylbutanol, hexanol, trans-3-hexen-1-ol, 2-heptanol, 6-methyl-5-hepten-2-ol, 1-octanol, benzyl alcohol, pentadecanol), five terpenes ( $\beta$-ocimene, terpinolene, $\beta$-linalool, terpinen-4-ol, alpha-terpineol), five ketones (2-pentanone, 3-hexanone, 2-heptanone, 6-methyl-5-hepten2-one, 3-nonanone), four hydrocarbons (heptadecane, octadecane, nonadecane, docosane) and one acid (octanoic acid), were detected in similar minor amounts in both passion fruit pulps.

Ethyl hexanoate, methyl hexanoate, $\beta$-myrcene and D-limonene were about twice as high in the organic passion fruit pulp and, methyl butanoate, butyl acetate, hexanal, 1-butanol, butyl butanoate, trans-3-hexenyl acetate, cis-3hexen-1-ol, butyl hexanoate, hexyl butanoate, 3-hexenyl butanoate and 3-hexenyl hexanoate were more than twice as high in the conventional passion fruit pulp (Table 2). The main differences between the aroma of organic and conventional passion fruit pulps could be attributed to these compounds. Ethyl butanoate, hexyl butanoate, ethyl hexanoate and hexyl hexanoate, responsible for the sweet, fruity and floral notes, and terpenes, are considered to be the most important for the characteristic passion fruit flavor (SHIBAMOTO; TANG, 1990; YOUNG; PATERSON, 1990; PINO; BOYS; RONCAL, 1995; WERKHOFF et al., 1998; JALES et al., 2005).

\section{Conclusions}

The aroma of the organic passion fruit pulp is mainly related to the volatile compounds ethyl hexanoate, methyl hexanoate, $\beta$-myrcene and D-limonene. The conventional passion fruit pulp showed methyl butanoate, butyl acetate, hexanal, 1-butanol, butyl butanoate, trans-3-hexenyl acetate, cis-3-hexen-1-ol, butyl hexanoate, hexyl butanoate, 3-hexenyl butanoate and 3-hexenyl hexanoate as the main volatile compounds for aroma.

\section{Acknowledgements}

The authors are grateful to FAPESP and PRODOC/CAPES for their financial support.

\section{References}

ACREE, T.; ARN, H. Flavornet. Disponível em: <http://www.flavornet. org/flavornet.html>. Acesso em: 20 mar. 2008.

ALMEIDA, C. O. Fruticultura brasileira em análise. Embrapa Mandioca e Fruticultura Tropical, 2008. Disponível em: <http:// 
www.portaldoagronegocio.com.br/conteudo.php?id=24830>. Acesso em: 20 mar. 2008.

AMARO, A. P.; MONTEIRO, M. Rendimento de extração da polpa e características físico-químicas do maracujá amarelo (Passiflora edulis F. Flavicarpa Sims. Deg.) produzido por cultivo orgânico e convencional em relação à cor da casca. Alimentos e Nutrição, v. 12, p. 171-184, 2001.

ASSOCIATION OF OFFICIAL ANALYTICAL CHEMISTS - AOAC. Official methods of analysis of the Association of Official Analytical Chemists. 16th ed. Washington: AOAC, 1998.

BASTOS, D. H. M.; DA SILVA, M. A. A. P.; FRANCO, M. R. B. Optimization of the isolation procedure of honey volatile compounds for further gas chromatography analysis. Alimentos e Nutrição, v. 9, p. 77-88, 1998.

BRASIL. Instrução Normativa $n^{\circ}$ 01, de 7 de janeiro de 2000. Regulamento técnico geral para fixação dos padrões de identidade e qualidade para polpa de fruta Ministério da Agricultura, Pecuária e Abastecimento. Diário Oficial da República do Brasil, Brasília, DF, 10 jan. 2000. Disponível em: <http://extranet.agricultura.gov. $\mathrm{br} /$ sislegis-consulta/servlet/VisualizarAnexo?id=1617>. Acesso em: 20 mar. 2008.

DE MARCHI, R. et al. Uso da cor da casca como indicador de qualidade do maracujá amarelo (Passiflora edulis Sims. F. flavicarpa Deg.) destinado à industrialização. Ciência e Tecnologia de Alimentos, v. 20 , n. 3 , p. 381-387, 2000. http://dx.doi.org/10.1590/S010120612000000300017

ENGEL, K. H.; TRESSL, R. Identification of new sulfur-containing volatiles in yellow passion fruits (Passiflora edulis F. flavicarpa). Journal of Agricultural and Food Chemistry, v. 39, p. 2249-2252, 1991. http://dx.doi.org/10.1021/jf00012a030

FRANCO, M. R. B.; RODRIGUEZ-AMAYA, D. B. Trapping of soursop (Annona muricata) juice volatiles on Porapak Q by suction. Journal of the Science of Food and Agriculture, v. 34, p. 293-299, 1983. http://dx.doi.org/10.1002/jsfa.2740340313

FRANCO, M. R. B.; SHIBAMOTO, T. Volatile composition of some brazilian fruits: umbu-cajá (Spondias citherea), camu-camu (Myrciaria dubia), araça-boi (Eugenia stipitata) and cupuaçu (Theobroma grandiflorum). Journal of Agricultural and Food Chemistry, v. 48, p. 1263-1265, 2000. PMid:10775382. http://dx.doi. org/10.1021/jf9900074

FRANCO, M. R. B.; RODRIGUEZ-AMAYA, D.; LANÇAS, F. M. Compostos voláteis de três cultivares de manga (Mangifera indica L.). Ciência e Tecnologia de Alimentos, v. 24, n. 2, p.165-169, 2004. http://dx.doi.org/10.1590/S0101-20612004000200002

GARRUTI, D. S. et al. Evaluation of volatile flavour compounds from cashew apple (Anacardium occidentale L.) juice by the Osme gas chromatography/olfactometry technique. Journal of the Science of Food and Agriculture, v. 83, p. 1455-1462, 2003. http://dx.doi. org/10.1002/jsfa.1560

HEIL, M.; BOSTOCK, R. M. Induced Systemic Resistance (ISR) Against Pathogens in the Context of Induced Plant Defenses. Annals of Botany, v. 89, n. 5, p. 503-512, 2002. PMid:12099523. http://dx.doi. org/10.1093/aob/mcf076
JALES, K. A. et al. Evaluación de los compuestos odoríferos del jugo de maracayá amarillo por GC-MS y GC-O (OSME). Noticias técnicas del laboratorio, v. 3, p. 1-3, 2005.

JANZANTTI, N. S.; FRANCO, M. R. B.; LANÇAS, F. M. Identificação de compostos voláteis de maçãs (Malus Domestica) cultivar Fuji, por cromatografia gasosa-espectrometria de massas. Ciência e Tecnologia de Alimentos, v. 20, n. 2, p. 164-171, 2000. http://dx.doi. org/10.1590/S0101-20612000000200007

JORDÁN, M. J.; GOODNER, K. L.; SHAW, P. E. Characterization of the aromatic profile in aqueous essence and fruit juice of yellow passion fruit (Passiflora edulis Sims F. Flavicarpa degner) by GC-MS and GC/O. Journal of Agricultural and Food Chemistry, v. 50, p. 1523-1528, 2002. http://dx.doi.org/10.1021/jf011077p

MACORIS, M. S.; JANZANTTI, N. S.; MONTEIRO, M. Isolamento dos compostos voláteis do maracujá orgânico por headspace dinâmico. In: ENCONTRO NACIONAL DE ANALISTAS DE ALIMENTOS E CONGRESSO LATINO AMERICANO DE ALIMENTOS ENAAL, 15., 2007, Fortaleza. Anais... Fortaleza, 2007. (1 CD-ROM).

MONTEIRO, M.; AMARO, A. P.; BONILHA, P. R. M. Avaliação físico-química e microbiológica da polpa de maracujá processada e armazenada sob refrigeração. Alimentos e Nutrição, v. 16, n. 1, p. 71-76, 2005.

NARAIN, N. et al. Compostos voláteis dos frutos de maracujá (Passiflora edulis forma Flavicarpa) e de cajá (Spondias mombin L.) obtidos pela técnica de headspace dinâmico. Ciência e Tecnologia de Alimentos, v. 24,n. 2, p. 212-216, 2004.

PINO, J. A. The volatile constituents of passion fruit. Alimentaria, v. 280, p. 73-81, 1997.

PINO, J. A.; BOYS, T.; RONCAL, E. Volatile components of passion fruit (Passiflora edulis F. flavicarpa) and its pasteurized pulp. Alimentaria, v. 268, p. 57-59, 1995.

SANTOS, G. C.; MONTEIRO, M. Sistema orgânico de produção de alimentos. Alimentos e Nutrição, v. 15, p. 73-86, 2004.

SHIBAMOTO, T.; TANG, C. S. Minor tropical fruits - Mango, papaya, passion fruit and guava. In: MORTON, I. D.; MACLEOD, A. J. (Eds.) Food Flavours Part C: The Flavour of Fruits. Amsterdam: Elsevier, 1990. p. 253-267.

THOMAZINI, M.; FRANCO, M. R. B. Metodologia para análise dos constituintes voláteis do sabor. Ciência e Tecnologia de Alimentos, v. 34, n. 1, p. 52-59, 2000.

WERKHOFF, P. et al. Vacuum headspace method in aroma research: flavor chemistry of yellow passion fruits. Journal of Agricultural and Food Chemistry, v. 46, p. 1076-1093, 1998. http://dx.doi. org/10.1021/jf970655s

WILLER, H.; YUSSEFI-MENZLER, M.; SORENSEN, N. The World of Organic Agriculture - Statistics and Emerging Trends 2008. Germany: IFOAM, Bonn and Switzerland, FiBL, Frick, 2008.

WINTERHALTER, P. Fruits IV. In: MAARSE, H. (Ed.) Volatile compounds in foods and beverage. New York: Marcel Dekker Inc., 1991. p. 389-409.

YOUNG, H.; PATERSON, V. The flavour of exotic fruit. In: MORTON, I. D.; MACLEOD, A. J. (Eds.) The Food Flavours. Part C: The flavour of fruits. Amsterdam: Elsevier, 1990. p. 281-326. 